\title{
Postheparin Plasma Lipoprotein and Hepatic Lipase Activities in Hyperinsulinemic Infants of Diabetic Mothers and in Large-for-Date Infants at Birth
}

\author{
LIISA M. ROVAMO, MARJA-RIITTA TASKINEN, TIMO KUUSI, AND KARI O. RAIVIO \\ Children's Hospital, Second and Third Departments of Medicine, and Department of Obstetrics and Gynecology, \\ University of Helsinki, Helsinki, Finland
}

\begin{abstract}
To study postheparin plasma lipase activities in nonfed newborn infants immediately after birth and to investigate the possible influence of fetal hyperinsulinemia on lipoprotein lipase activity, we measured lipoprotein and hepatic lipase activities in $\mathbf{5 5}$ macrosomic newborn infants: group I consisted of 21 infants born to mothers with insulindependent diabetes. The infants were hyperinsulinemic at birth and had hypoglycemia and poor lipolysis at the age of $2 \mathrm{~h}$. Group II consisted of 18 infants born to mothers with gestational diabetes. Group III consisted of 16 largefor-date infants born to nondiabetic mothers. The mean postheparin plasma lipoprotein lipase activities at $2 \mathrm{~h}$ of age were similar (mean $36 \mu \mathrm{mol}$ free fatty acids $/ \mathrm{ml} / \mathrm{h} ; \mathrm{SEM}$ 15) in groups I-III. Lipoprotein lipase activity correlated negatively with cord-serum triglycerides (range 0.13-1.2 $\mathrm{mmol} / \mathrm{liter}$ ) but did not correlate with serum insulin (range 5.4-524 $\mu \mathrm{U} / \mathrm{ml}$ ) or C-peptide (range 0.6-21.0 $\mu \mathrm{g} / \mathrm{liter}$ ). Hepatic lipase activity was somewhat higher in group I (mean $68 \mu \mathrm{mol}$ free fatty acids/ml/h; SEM 23) than in groups II and III (mean $55 \mu \mathrm{mol}$ free fatty acids $/ \mathrm{ml} / \mathrm{h}$; SEM 14). Hemoglobin Alc was the only important factor explaining the difference in hepatic lipase activities between groups. Lipoproteins and apolipoproteins A-I, A-II, and $B$ were similar in all three groups. We conclude that in large-for-date infants lipoprotein lipase is active at birth without exogenous fat induction, and that these infants are capable of hydrolyzing fat, their main source of energy, immediately after birth. In addition, we conclude that postheparin plasma lipoprotein lipase activity is not affected by fetal hyperinsulinemia. (Pediatr Res 20: 527531,1986 )
\end{abstract}

\section{Abbreviations}

FFA, free fatty acids

Hb, hemoglobin

Soon after birth fat becomes the major metabolic fuel (1): breast-milk fat is readily absorbed through the bowel wall as chylomicrons and liver produces endogenous lipoproteins into

Received July 17, 1985; accepted January 30, 1986.

Reprint requests Liisa Rovamo, M.D., Children's Hospital, University of Helsinki, Stenbäckinkatu 11, SF-00290 Helsinki, Finland.

Supported by The Foundation for Pediatric Research, Heikki and Hilma Honkanen's Foundation, Foundation of Nutrition Research, Finnish Cultural Foundation, Sigrid Juselius Foundation, The Academy of Finland, and Huhtamäki Inc., Leiras Pharmaceuticals. the circulation (2). Triglycerides in chylomicrons and very lowdensity lipoproteins of plasma are hydrolyzed by lipoprotein lipase $(3,4)$. The lipase is located on the vascular endothelial surface of adipose and muscle tissue. It is released into the circulation by heparin. Heparin also releases hepatic lipase from the vascular endothelial surface of the liver. In contrast to lipoprotein lipase, the function of hepatic lipase in lipoprotein metabolism has not been fully established $(4,5)$.

On the basis of animal experiments, lipoprotein lipase activity of newborn infants has been suggested to be low at birth and to increase postnatally $(1,6,7)$. If so, infants at birth might be incapable of using fat effectively for energy. Previously, we have shown that at the age of 1 to 4 days postheparin plasma lipoprotein lipase is already at the adult level in breast-milk-fed term and preterm infants; their hepatic lipase activity is about three times the adult value $(8,9)$. On the other hand, we found that lipoprotein lipase activity increases during the first days of life whereas hepatic lipase activity remains unchanged in infants receiving fat-containing parenteral nutrition (10).

Fetal hyperinsulinemia is associated with macrosomia, hypoglycemis, and inhibition of lipolysis in infants born to diabetic mothers (11). In adults, insulin is known to induce lipoprotein lipase $(3,12)$, and lipoprotein lipase activity of adipose tissue has been reported to be high in obese adults whose basal serum insulin level is elevated $(13,14)$. This suggests that fetal hyperinsulinemia associated with maternal diabetes mellitus may induce lipoprotein lipase activity perinatally.

To investigate the levels of postheparin plasma lipases immediately after birth in large-for-date infants and to study the possible inducing effect of intrauterine insulin on lipoprotein lipase, we measured lipoproteine and hepatic lipase activities in hyperinsulinemic infants born to diabetic mothers, in infants born to gestationally diabetic mothers, and in large-for-date infants born to nondiabetic mothers.

\section{MATERIALS AND METHODS}

Subjects. A total of 55 infants were studied. They belonged to one of the following three groups:

Group I consisted of 21 infants born to insulin-dependent diabetic mothers (three of White's class A/B (15), eight of class $\mathrm{B}$, six of class $\mathrm{C}$, and four of class D). The antenatal and obstetric care of the mothers was as previously described (16-18). During the last trimester of pregnancy the mean $\mathrm{Hb}$ Alc was $6.7 \%$ of total hemoglobin [range 5.6-8.9\% $\mathrm{Hb}$; mean $+\mathrm{SD}$ for normal pregnant women in the 3rd trimester is in our laboratory $5.0+$ $0.5 \% \mathrm{Hb}(19)$ ]. During the week preceding delivery the mean $\mathrm{Hb}$ Alc was $6.4 \% \mathrm{Hb}$ (range $5.0-8.2 \% \mathrm{Hb}$ ).

After ascertainment of lung maturity by amniocentesis (20), 
labor was induced in eight mothers whereas 13 mothers underwent elective cesarean section. On the morning of intended delivery, the mothers received $12 \mathrm{U}$ of short-acting insulin subcutaneously, followed by a glucose infusion at a rate of $4 \mathrm{mg}$ / $\mathrm{kg} / \mathrm{min}$; subsequent doses of insulin were adjusted to maintain normoglycemia.

Gestational ages of 14 boys and 7 girls ranged from 34 to 38 wk (mean 37.6), birth weights from 2660 to $4780 \mathrm{~g}$ (mean 3891 $\mathrm{g}$ ), and relative birth weights from -0.5 to $4.5 \mathrm{SD}$ units (mean 2.2). Relative birth weight refers to the deviation of the individual birth weight from the mean birth weight for gestational age (21) divided by the corresponding SD (21). One infant had an Apgar score of 3 at $1 \mathrm{~min}$ but 7 at $5 \mathrm{~min}$ of age; all others scored from 7 to 10 at $1 \mathrm{~min}$ of age.

Group II consisted of 18 infants born to mothers with gestational diabetes: blood glucose concentration exceeded $140 \mathrm{mg} /$ $\mathrm{dl}$ at $2 \mathrm{~h}$ in an oral glucose $(50 \mathrm{~g})$ tolerance test. The mothers were treated by diet alone. At the time of delivery the mean $\mathrm{Hb}$ Alc was $5.4 \%$ of total $\mathrm{Hb}$ (range $4.7-6.0 \% \mathrm{Hb}$ ). During delivery the mothers received glucose infusion at a rate of $4 \mathrm{mg} / \mathrm{kg} / \mathrm{min}$ but no insulin. Sixteen infants were born through the vaginal route and two by cesarean section. Gestational age of 12 boys and six girls ranged from 37 to $42 \mathrm{wk}$ (mean 39.4), birth weights from 3140 to $4670 \mathrm{~g}$ (mean $3820 \mathrm{~g}$ ), and relative birth weights from -0.3 to $2.7 \mathrm{SD}$ units (mean 1.1). Apgar scores ranged from 7 to 10 at $1 \mathrm{~min}$ of age.

Group III consisted of 16 large-for-date infants born to mothers whose oral glucose tolerance tests were normal. At the time of delivery the mean $\mathrm{Hb}$ Alc was $5.7 \%$ of total $\mathrm{Hb}$ (range $4.7-6.5 \%$ $\mathrm{Hb}$ ). Twelve of the mothers received glucose infusion at a rate of $0.2-2.5 \mathrm{mg} / \mathrm{kg} / \mathrm{min}$ during delivery. Thirteen infants were born through the vaginal route and three by cesarean section. Gestational ages of nine boys and seven girls ranged from 39 to $42 \mathrm{wk}$ (mean 41.2), birth weights from 4500 to $5970 \mathrm{~g}$ (mean $4811 \mathrm{~g}$ ), and relative birth weights from 2.0 to $5.8 \mathrm{SD}$ units (mean 2.7). Apgar scores ranged from 7 to 10 at $1 \mathrm{~min}$ of age.

The purpose of the investigation was explained to both parents and the investigation was carried out with their consent. The experimental protocol was approved of by the Ethical Committee, Department of Obstetrics and Gynecology, University of Helsinki. Ethical considerations precluded the study of infants with normal birth weights born to nondiabetic mothers.

Experimental protocol. Immediately after birth a sample of mixed cord blood was deproteinized for the measurement of glucose and $\beta$-hydroxybutyrate concentrations (groups I and II). Another sample of cord blood was centrifuged at $+4^{\circ} \mathrm{C}$. Part of the serum was stored at $-20^{\circ} \mathrm{C}$ for the assays of insulin and $\mathrm{C}$ peptide, FFA, and apolipoproteins. The rest of the serum was ultracentrifuged for the separation of the lipoprotein classes.

During the first hours of life the infants were under careful observation: blood pressure, respiratory rate, heart rate, and heel and rectal temperatures were recorded every $10 \mathrm{~min}$; all infants remained in good condition.

At the age of $2 \mathrm{~h}$, a blood sample was taken through an indwelling peripheral vein catheter for the measurement of blood glucose and $\beta$-hydroxybutyrate, serum insulin or free insulin,

Table 1. Hormonal and metabolic parameters at birth and $2 h$ of age: mean (range)

\begin{tabular}{|c|c|c|c|c|c|}
\hline & $n$ & Cord blood & $n$ & $2 \mathrm{~h}$ & $p$ value* \\
\hline \multicolumn{6}{|l|}{ Serum C-peptide ( $\mu \mathrm{g} /$ liter) } \\
\hline Group I & 20 & $5.9(1.1-21)$ & & & \\
\hline Group II & 18 & $2.0(0.7-4.7)$ & & & \\
\hline Group III & 16 & $1.8(0.6-3.7)$ & & & \\
\hline$p$ value $\dagger$ & & $p<0.001$ & & & \\
\hline \multicolumn{6}{|l|}{ Serum insulin $(\mu U /$ liter $)$} \\
\hline Group I (free insulin) & 21 & $120(7.2-520)$ & 19 & $26(0.7-77)$ & $p<0.001$ \\
\hline Group II & 18 & $30(5.4-100)$ & 15 & $13(2.9-30)$ & $p<0.05$ \\
\hline Group III & 16 & $27(7.5-100)$ & 16 & $29(4.5-130)$ & NS \\
\hline$p$ value $\dagger$ & & $p<0.001$ & & $p<0.05$ & \\
\hline \multicolumn{6}{|c|}{ Blood glucose (mmol/liter) } \\
\hline Group I & 18 & $5.9(2.2-12)$ & 20 & $1.2(0.5-2.5)$ & $p<0.0001$ \\
\hline Group II & 14 & $5.9(1.8-9.5)$ & 18 & $2.1(1.1-3.0)$ & $p<0.0001$ \\
\hline Group III & & & 16 & $2.1(1.3-3.0)$ & \\
\hline$p$ value $\dagger$ & & NS & & $p<0.0001$ & \\
\hline \multicolumn{6}{|c|}{ Serum triglycerides (mmol/liter) } \\
\hline Group I & 21 & $0.41(0.13-1.2)$ & 19 & $0.59(0.36-0.88)$ & $p<0.05$ \\
\hline Group II & 18 & $0.41(0.22-0.65)$ & 18 & $0.63(0.14-0.97)$ & $p<0.05$ \\
\hline Group III & 15 & $0.39(0.21-0.58)$ & 16 & $0.60(0.18-0.84)$ & $p<0.05$ \\
\hline$p$ value $\dagger$ & & NS & & NS & \\
\hline \multicolumn{6}{|l|}{ Serum FFA (mmol/liter) } \\
\hline Group I & 21 & $0.20(0.06-0.58)$ & 20 & $0.27(0.05-0.82)$ & NS \\
\hline Group II & 18 & $0.18(0.07-0.28)$ & 18 & $0.70(0.13-1.7)$ & $p<0.001$ \\
\hline Group III & 16 & $0.22(0.10-0.41)$ & 16 & $0.77(0.20-1.7)$ & $p<0.001$ \\
\hline$p$ value $\dagger$ & & NS & & $p<0.0001$ & \\
\hline \multicolumn{6}{|c|}{ Blood $\beta$-hydroxybutyrate ( $\mathrm{mmol} /$ liter) } \\
\hline Group I & 16 & $0.80(0.13-3.2)$ & 20 & $0.21(0.41-0.39)$ & $p<0.05$ \\
\hline Group II & 14 & $0.63(0.21-1.5)$ & 17 & $0.21(0.14-0.27)$ & $p<0.05$ \\
\hline Group III & & & 16 & $0.24(0.18-0.34)$ & \\
\hline$p$ valuet & & NS & & NS & \\
\hline
\end{tabular}

* Comparing cord-blood and 2-h values.

$\dagger$ Comparing groups. 
FFA, and triglycerides, and plasma basal activities of lipoprotein and hepatic lipases. Thereafter, a heparin (Medica, Helsinki, Finland) bolus of $100 \mathrm{IU} / \mathrm{kg}$ was injected through the catheter. Fifteen minutes later a blood sample was taken for the measurement of lipase activities. Then the infants received their first feeding of breast milk. As shown previously $(8-10)$, the infants showed no signs of bleeding tendency or other side-effects resulting from heparin administration. Five infants of group I and one of group III received intravenous glucose because of hypoglycemia during the first days of life.

Analytical methods. Serum C-peptide, serum insulin, and free insulin were measured with radioimmunoassay methods $(22$, 23). Serum FFA concentration was measured with an enzymatic method (Nefa C-Test, Wako, Wako Pure Chemical Industries LTD, Japan). Blood $\beta$-hydroxybutyric acid concentration was measured with a fluorometric method (24).

Separation of serum lipoproteins was done using a Ti-50.3 rotor in a Beckman L7-70 ultracentrifuge (Beckman Instruments, Inc., Palo Alto, CA). Lipoproteins (very low-density lipoproteins, low-density lipoproteins, high-density lipoproteins 2 , and high-density lipoproteins 3 ) were separated by sequential spinning at densities $1.006,1.063,1.125$, and $1.21 \mathrm{~g} / \mathrm{ml}$ for 18 , 24,65 , and $65 \mathrm{~h}$, respectively. Triglyceride and cholesterol concentrations in serum and in lipoprotein fractions were measured with enzymatic methods (kit nos. 297771 and 187313, Boehringer Diagnostica GmbH, Mannheim, West Germany). Phospholipid concentrations in serum and lipoprotein fractions were measured as inorganic phosphate (25) and protein concentrations with the Lowry method (26). Serum apolipoprotein A-I, A-II and $B$ concentrations were measured with a radial immunodiffusion method $(27,28)$.

The lipoprotein and hepatic lipase activities of postheparin plasma were measured with the immunochemical method of Huttunen et al. (29): lipoprotein lipase was measured after inactivating hepatic lipase with a specific antiserum and hepatic lipase was measured at $1 \mathrm{M} \mathrm{NaCl}$ concentration which inactivates lipoprotein lipase, no serum was added.

Statistical methods. Statistical analyses were performed by means of BMDP statistical software. We used one-way analysis of variance and unpaired $t$ test for comparing groups I-III and the paired $t$ test for comparing cord-blood and $2-\mathrm{h}$ values. In addition, we computed correlation coefficients between lipases and the other parameters measured and performed covariance analyses when the other parameters were found to correlate mutually.

\section{RESULTS}

Hormonal and metabolic parameters. The parameters were measured to evaluate hyperinsulinemia at birth and to assess the extent of hypoglycemia and lipolysis at the age of $2 \mathrm{~h}$ in our nonfed infants. Table 1 compares the values measured in cord blood and at the age of $2 \mathrm{~h}$.

The results indicate that the infants born to insulin-dependent diabetic moethers were hyperinsulinemic at birth and that they became hypoglycemic and had low FFA levels suggesting poor lipolysis at the age of $2 \mathrm{~h}$.

Cord serum lipoproteins and apoproteins. The mean serum concentrations of triglycerides, cholesterol, phospholipids, and proteins in lipoprotein classes of cord serum (Table 2) were similar in groups I-III. Also, the concentrations of apolipoproteins A-I, A-II, and B (Table 2) were similar in all groups.

Postheparin plasma lipoprotein lipase at the age of $2 \mathrm{~h}$. There was no measurable lipase activity in the blood samples taken before the heparin administration. Fifteen minutes after the heparin bolus of $100 \mathrm{IU} / \mathrm{kg}$, the mean activity of lipoprotein lipase, expressed in $\mu \mathrm{mol} \mathrm{FFA} / \mathrm{ml} / \mathrm{h}$, was 38.9 in group I, 35.7 in group II, and 33.0 in group III (Fig. $1 A$ ); the values were not statistically different $(p>0.5)$. Taking all three groups together, postheparin-plasma lipoprotein lipase activities at the age of $2 \mathrm{~h}$
Table 2. Liprotein-lipids and apoproteins $A-I, A-I I$, and $B$ in cord serum (mean $\pm S E M)^{*}$

\begin{tabular}{lrrr}
\hline & \multicolumn{3}{c}{ Group } \\
\cline { 2 - 4 } & \multicolumn{1}{c}{ I } & \multicolumn{1}{c}{ II } & \multicolumn{1}{c}{ III } \\
\hline Triglycerides (mg/dl) & $35.8 \pm 5.0$ & $35.9 \pm 2.9$ & $34.1 \pm 2.7$ \\
VLDL $\dagger$ & $8.7 \pm 2.2$ & $8.2 \pm 1.4$ & $7.4 \pm 1.3$ \\
LDL & $14.5 \pm 1.6$ & $12.2 \pm 1.2$ & $12.9 \pm 1.2$ \\
HDL & $13.8 \pm 2.4$ & $14.5 \pm 1.5$ & $13.9 \pm 1.2$ \\
HDL2 & $10.3 \pm 2.9$ & $6.6 \pm 0.9$ & $8.2 \pm 0.9$ \\
HDL3 & $6.3 \pm 1.2$ & $7.9 \pm 1.2$ & $5.7 \pm 0.7$ \\
& & & \\
Cholesterol (mg/dl) & $69.1 \pm 3.8$ & $69.2 \pm 3.8$ & $66.7 \pm 3.6$ \\
VLDL & $2.5 \pm 0.5$ & $2.5 \pm 0.5$ & $2.3 \pm 0.6$ \\
LDL & $31.5 \pm 1.8$ & $29.3 \pm 2.2$ & $30.3 \pm 2.1$ \\
HDL & $38.3 \pm 2.5$ & $36.0 \pm 2.6$ & $35.1 \pm 2.1$ \\
HDL2 & $22.3 \pm 1.8$ & $19.3 \pm 2.1$ & $20.8 \pm 1.6$ \\
HDL3 & $15.9 \pm 1.0$ & $16.8 \pm 1.6$ & $16.4 \pm 1.1$ \\
& & & \\
Phospholipids (mg/ & $91.7 \pm 5.6$ & $84.0 \pm 3.1$ & $80.2 \pm 4.4$ \\
$\quad$ dl) & & & \\
VLDL & $2.5 \pm 0.6$ & $2.5 \pm 0.4$ & $2.5 \pm 0.4$ \\
LDL & $23.5 \pm 1.7$ & $20.1 \pm 0.9$ & $19.4 \pm 1.1$ \\
HDL & $65.8 \pm 4.3$ & $61.4 \pm 2.6$ & $58.3 \pm 3.6$ \\
HDL2 & $32.0 \pm 2.8$ & $26.4 \pm 2.5$ & $25.2 \pm 1.7$ \\
HDL3 & $23.0 \pm 1.4$ & $24.3 \pm 1.7$ & $21.3 \pm 1.5$ \\
& & &
\end{tabular}

$\begin{array}{lccc}\text { Proteins }(\mathrm{mg} / \mathrm{dl}) & & & \\ \quad \text { VLDL } & 6.8 \pm 1.5 & 12.3 \pm 3.2 & 11.7 \pm 2.1 \\ \text { LDL } & 38.7 \pm 5.9 & 32.9 \pm 3.3 & 38.4 \pm 5.4 \\ \text { HDL } & 103 \pm 8.8 & 119 \pm 11 & 120 \pm 11 \\ \text { HDL2 } & 44.8 \pm 4.8 & 42.8 \pm 4.5 & 53.8 \pm 9.4 \\ \text { HDL3 } & 58.7 \pm 5.1 & 76.5 \pm 11 & 71.9 \pm 7.4 \\ \text { Apo A-I }(\mathrm{mg} / \mathrm{dl}) & 96.4 \pm 4.7 & 103 \pm 3.5 & 97.2 \pm 2.3 \\ & & & \\ \text { Apo A-II }(\mathrm{mg} / \mathrm{dl}) & 28.0 \pm 1.6 & 30.9 \pm 1.1 & 27.8 \pm 1.0 \\ & & & \\ \text { Apo B }(\mathrm{mg} / \mathrm{dl}) & 29.2 \pm 1.3 & 27.7 \pm 1.2 & 27.4 \pm 0.9\end{array}$

* The number of infants was 19 in group I, 17 in group II, and 15 in group III.

$\dagger$ VLDL, very low-density lipoproteins; LDL, low-density lipoproteins; HDL, high-density lipoprotein.

in these nonfed infants ranged from 12.7 to $81.9 \mu \mathrm{mol} \mathrm{FFA} / \mathrm{ml} /$ $\mathrm{h}($ Fig. $1 A$ ). In a group consisting of 34 healthy medical students the mean postheparin-plasma lipoprotein lipase activity was 17.4 $\mu \mathrm{mol} \mathrm{FFA} / \mathrm{ml} / \mathrm{h}$ (range 6.6-35.2) (8). The lipoprotein lipase activities of our infants correlated negatively with total triglycerides $(r=-0.38, p<0.01)$, very low-density lipoproteintriglycerides $(r=-0.33, p<0.05)$, and low-density lipoproteintriglycerides $(r=-0.45, p<0.01)$ of cord blood.

The infants of group I were hyperinsulinemic. Nevertheless, their lipoprotein lipase activities were comparable to values observed in infants in groups II and III. Taking all groups together, lipoprotein lipase activity was independent of cordserum C-peptide and insulin. In addition, lipoprotein lipase activity was independent of birth weight and gestational age.

Postheparin plasma hepatic lipase at the age of $2 \mathrm{~h}$. There was no measurable lipase activity in the blood samples taken before the heparin administration. Fifteen minutes after the heparin bolus, the mean hepatic lipase activity, expressed in $\mu$ mol FFA/ $\mathrm{ml} / \mathrm{h}$, was 68.3 in group I, 58.7 in group II, and 52.3 in group III (Fig. $1 B$ ). Hepatic lipase activity was in group I somewhat higher $(p<0.05)$ than in groups II and III.

Taking all three groups together, hepatic lipase activity correlated negatively $(r=-0.43, p<0.01)$ with gestational age, but positively with cord serum C-peptide $(r=0.33, p<0.05)$ and 

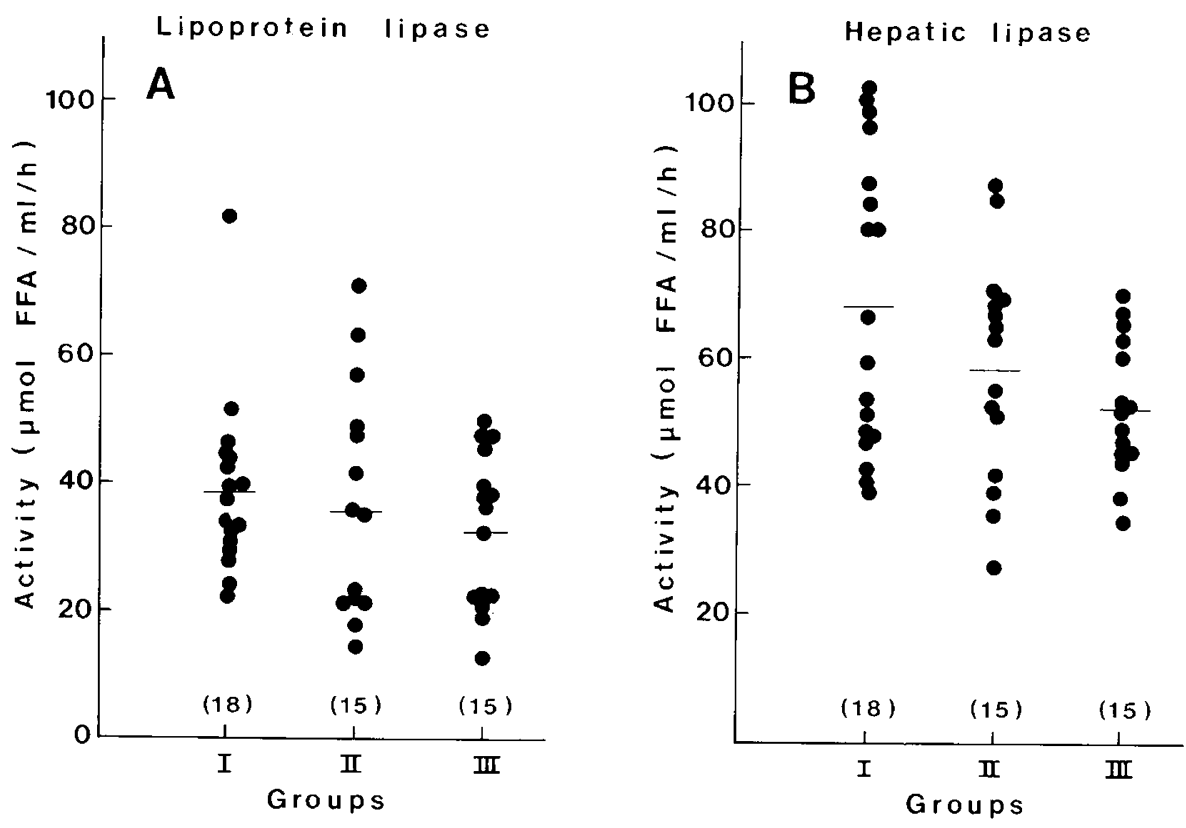

Fig. 1. Postheparin plasma lipoprotein $(A)$ and hepatic lipase $(B)$ activities of newborn infants. In group I the infants were born to insulindependent diabetic mothers and in group II to gestationally diabetic mothers. Group III consisted of large-for-date reference infants. Horizontal lines indicate the mean lipase activites. In $B p<0.05$ when comparing groups I-III.

the $\mathrm{Hb}$ Alc of mother $(r=0.54, p<0.01)$. However, gestational age, C-peptide, and $\mathrm{Hb}$ Alc correlated mutually. Covariance analysis showed that $\mathrm{Hb} \mathrm{AlC}$ was the only important $(p<0.05)$ factor explaining the variation of hepatic lipase.

\section{DISCUSSION}

In animals, lipoprotein lipase activity has been found to increase postnatally $(1,6)$. We found, however, that at the age of $2 \mathrm{~h}$ the mean lipoprotein lipase activity in our infants was higher than in term and preterm infants at the age of 1 to 4 days (mean $+\mathrm{SD}, 19.7+10.5 \mu \mathrm{mol} \mathrm{FFA} / \mathrm{ml} / \mathrm{h}$ ) or in adults (mean $+\mathrm{SD}$, $17.4+6.3 \mu \mathrm{mol} \mathrm{FFA} / \mathrm{ml} / \mathrm{h})(8,9)$. Most of our infants were, however, large-for-date (relative birth weight $>2.0 \mathrm{SD}$ units) and thus had more fat tissue, which might account for the higher lipoprotein lipase activity. Lipoprotein lipase activity was, however, independent of birth weight.

As in animals (6), exogenous fat has been suggested to induce lipoprotein lipase activity in man $(10,30)$. However, in our infants lipoprotein lipase was high although they had not been fed.

Lipoprotein lipase activity at the age of $2 \mathrm{~h}$ correlated negatively with cord-serum triglyceride concentration. This implies that lipoprotein lipase can hydrolyze fat at birth. Thus, active lipoprotein lipase may help to prevent hypoglycemia by producing glycerol for gluconeogenesis and FFA for oxidation in tissues. In agreement, administration of fat has been shown to increase blood glucose levels in hypoglycemic small-for-date newborn infants (31) and in starved newborn rats (32). Furthermore, lipoprotein lipase may be significant even for fetal fat storage by shuttling triglycerides for peripheral uptake, as has been proposed to occur in rats with active lipoprotein lipase in adipose tissue at birth $(1,33)$.

In the infants born to insulin-dependent diabetic mothers (group I) the mean cord-serum insulin level was five times and C-peptide level three times the levels found in the other two infant groups studied. At the age of $2 \mathrm{~h}$, when lipoprotein lipase activity was measured, there was still a profound postnatal effect of insulin in group I: glucose and FFA levels were low although the difference in insulin concentrations between groups I and III had already disappeared. There were, however, no differences in lipoprotein lipase activities between groups I-III, although insulin is known to induce lipoprotein lipase in adults $(3,12)$. The infants born to insulin-dependent diabetic mothers had a lower gestational age (37.6 wk) than large-for-date infants $(41.2 \mathrm{wk})$, which might mask the inducing effect of insulin. On the other hand, lipoprotein lipase activity was high in almost all of our infants whereas insulin has been shown to be capable of increasing lipoprotein lipase activity in adult adipose tissue only if the basal lipoprotein lipase activity is low $(34,35)$. Therefore, the similarity of lipoprotein lipase activities in groups I-III can be explained by assuming saturation of insulin induction.

In the hyperinsulinemic infants of group I the mean hepatic lipase activity was somewhat higher than in groups II and III. The mean activity of postheparin-plasma hepatic lipase groups II and III was as in term and preterm infants (mean + SD, 57.5 $+27.7 \mu \mathrm{mol} \mathrm{FFA} / \mathrm{ml} / \mathrm{h}$ ) but almost three times higher than in adults (mean $+\mathrm{SD}, 23.1+10.6 \mu \mathrm{mol} \mathrm{FFA} / \mathrm{ml} / \mathrm{h})(8,9)$. According to covariance analysis the only important factor explaining the variation of hepatic lipase in groups I-III was Hb Alc of the mothers. A high HbAlc level is an indicator of poor balance of diabetes, which often produces macrosomia of infants during the last trimester of pregnancy $(11,18)$. This provides an explanation for the positive correlation between hepatic lipase activity and the level of HbAlc, because hepatic lipase activity is released from the liver, which is large in macrosomic infants.

Cord-serum lipoproteins in our infants were as in normal term infants (36-40). In addition, cord-serum lipoproteins and apolipoproteins were similar in all three groups, although infants born to diabetic mothers have been reported to have higher cholesterol and lower triglyceride levels than normal term infants $(41,42)$. One possible explanation for this discrepancy is a difference in gestational age: most of our infants were born at term whereas in previous reports infants have been preterm $(41,42)$.

In conclusion, lipoprotein lipase was active in large-for-date newborn infants immediately after birth and without exogenous fat induction. High lipase activity and its negative correlation with cord-serum triglycerides implies that these newborn infants can efficiently hydrolyze fat at birth. Although insulin is known to induce lipoprotein lipase in adults, lipoprotein lipase activity was independent of serum insulin level in our hyperinsulinemic infants. 
Acknowledgments. The authors thank Mrs. Sirkka Runeberg, Miss Paula Teräväinen, Mrs. Leena Lehikoinen, and Mrs. Hannele Hilden for their skillful technical assistance.

\section{REFERENCES}

1. Hahn P 1978 Lipids. In: Stave U (ed) Perinatal Physiology, 2nd ed. Medical Book Co, New York, pp 397-423

2. Levene MI 1981 Tolerance of parenteral fat in the preterm neonate. In: Wosdorp, Ric, Soeters (eds) Clinical Nutrition 81', Churchill Livingstone, New York, pp 97-104

3. Cryer A 1981 Tissue lipoprotein lipase activity and its action in lipoprotein metabolism. Int J Biochem 13:525-541

4. Jackson RL 1983 Lipoprotein lipase and hepatic lipase. In: Boyer PD (ed) The Enzymes. Academic Press, New York, pp 141-181

5. Jansen H, Birkenhager JC 1981 Liver lipase-like activity in human and hamster adrenocortical tissue. Metabolism 30:428-430

6. Das JB, Joshi IK, Philippart AI 1982 Postnatal development of lipid-clearing enzymes in the suckling animal. J Pediatr Surg 17:914-919

7. Rosseneu M, van Biervliet JP, Bury J, Vinaimont N 1983 Isolation and characterization of lipoprotein profiles in newborns by density gradient ultracentrifugation. Pediatr Res 17:788-794

8. Rovamo L, Taskinen MR, Kuusi T, Nikkilä EA, Ehnholm C, Raivio KO 1984 Postheparin plasma lipase activities and plasma lipoproteins in newborn infants. Pediatr Res 18:642-647

9. Rovamo L, Nikkilä EA, Taskinen MR, Raivio KO 1984 Postheparin plasma lipoprotein and hepatic lipases in preterm neonates. Pediatr Res 18:11041107

10. Rovamo L 1985 Postheparin plasma lipases and carnitine in infants during parenteral nutrition. Pediatr Res 19:292-297

11. Cowett RM, Schwartz R 1982 The infant of the diabetic mother. Pediatr Clin North Am 29:1213-123

12. Sadur CN, Eckel RH 1982 Insulin stimulation of adipose tissue lipoprotein lipase. Use of the euglycemic clamp technique. J Clin Invest 69:1119-1125

13. Nilsson-Ehle $P 1981$ Impaired regulation of adipose tissue lipoprotein lipase in obesity. Int J Obesity 5:695-699

14. Pykälistö OJ, Smith PH, Brunzell JD 1975 Determinants of human adipose tissue lipoprotein lipase. Effect of diabetes and obesity on basal- and dietinduced activity. $\mathrm{J}$ Clin Invest 56:1108-1117

15. White P 1965 Pregnancy and diabetes, medical aspects. Med Clin North Am 49:1015-1024

16. Teramo K, Kuusisto AN, Raivio KO 1979 Perinatal outcome of insulindependent diabetic pregnancies. Ann Clin Res 11:146-155

17. Teramo K, Ämmälä P, Ylinen K, Raivio KO 1983 Pathologic fetal heart rate associated with poor metabolic control in diabetic pregnancies. Obstet Gynecol 61:559-565

18. Ylinen K, Raivio K, Teramo K 1981 Haemoglobin Alc predicts the perinatal outcome in insulin-dependent diabetic pregnancies. $\mathrm{Br} \mathbf{J}$ Obstet Gynaecol 88:961-967

19. Ylinen K, Hekali R, Teramo K 1981 Haemoglobin Alc during pregnancy of insulin-dependent diabetics and health controls. J Obstet Gynaecol 1:223228

20. Hallman M, Teramo K 1979 Amniotic fluid phospholipid profile as a predictor of fetal maturity in diabetic pregnancies. Obstet Gynecol 54:703-709

21. Usher R, McLean F 1969 Intrauterine growth in live-born caucasian infants at sea level: standards obtained from measurements in 7 dimensions of infants born between 25 and 44 weeks of gestation. J Pediatr 74:901-910

22. Desbuquois B, Aurbach GD 1971 Use of polyethylene glycol to separate free and antibody-bound peptide hormones in radioimmunoassays. J Clin Endocrinol 33:732-738

23. Kuzuya H, Blix PM, Horwitz DL, Steiner DF, Rubenstein AH 1977 Determination of free and total insulin and C-peptide in insulin-treated diabetics. Diabetes 26:22-29

24. Olsen C 1971 An enzymatic fluorimetric micromethod for the determination of acetoacetate, 3-hydroxybutyrate, pyruvate and lactate. Clin Chem Acta 33:293-296

25. Bartlett GR 1959 Phosphorus assays in column chromatography. J Biol Chem 234:466-469

26. Lowry OH, Rosebrough NJ, Farr AI, Randall RJ 1951 Protein measurement with the folin phenol reagent. J Biol Chem 193:265-275

27. Cheung MC, Albers JJ 1977 The measurement of apolipoprotein A-I and A-II levels in men and women by immunoassay. $\mathrm{J}$ Clin Invest 60:43-50

28. Curry MD, Gustafson A, Alaupovic P, McConathy WJ 1978 Electroimmunoassay, and radial immunodiffusion assay evaluated for quantification of human apolipoprotein B. Clin Chem 24:280-286

29. Huttunen JK, Ehnholm C, Kinnunen PKJ, Nikkilä EA 1975 An immunochemical method for the selective measurement of two triglyceride lipases in human postheparin plasma. Clin Chim Acta 63:335-347

30. Taskinen MR, Tulikoura I, Nikkilä EA, Ehnholm C 1981 Effect of parenteral hyperalimentation on serum lipoproteins and on lipoprotein lipase activity of adipose tissue and skeletal muscle. Eur $J$ Clin Invest 11:317-323

31. Mestyan J, Rubecz I, Soltesz G 1976 Changes in blood-glucose, free fatty acid and amino-acids in low-birth-weight infants receiving intravenous fat emulsion. Biol Neonate 30:74-79

32. Ferre PR, Pegorier JP, Girard JR, Marliss EB 1977 Evidence that fatty acid oxidation stimulates gluconeogenesis in newborn rats. Biochem Soc Trans 5:982-990

33. Cryer A 1985 Lipoprotein lipase and the uptake of lipid by adipose cells during development. Reprod Nutr Dev 25:255-270

34. Taskinen MR, Nikkilä EA 1979 Lipoprotein lipase activity of adipose tissue and skeletal muscle in insulin-deficient human diabetes. Diabetologia 17:351-356

35. Yki-Järvinen H, Taskinen MR, Koivisto VA, Nikkilä EA 1984 Response of adipose tissue lipoprotein lipase activity and serum lipoproteins to acute hyperinsulinaemia in man. Diabetologia 27:364-369

36. Ginsburg BE, Zetterström R 1980 Serum cholesterol concentrations in early infancy. Acta Paediatr Scand 69:581-585

37. Hardell $\mathrm{Li}$ Serum lipids and lipoproteins at birth based on a study of 2815 newborn infants. I. Concentrations and distributions of triglycerides and cholesterol. Acta Paediatr Scand Supply 285:5-10

38. McConathy WJ, Lane DM 1980 Studies on the apolipoproteins and lipoproteins of cord serum. Pediatr Res 14:757-76

39. Strobl W, Widhalm K, Kostner G, Pollak A 1983 Serum apolipoproteins and lipoproteins during the first week of life. Acta Paediatr Scand 72:505-509

40. van Biervliet JP, Vinaimont N, Caster H, Vercaemst R, Rosseneu M 198 Plasma apoprotein and lipid patterns in newborns: influence of nutritional factors. Acta Paediatr Scand 70:851-856

41. Andersen GE, Lous P, Friis-Hansen B 1979 Hyperlipoproteinemia in newborn infants. A study of 1025 families. Acta Paediatr Scand 68:683-690

42. Hardell LI Serum lipids and lipoproteins at birth based on a study of 2815 newborn infants. II. Relations between materno-foetal factors and the concentrations of triglycerides and cholesterol. Acta Paediatr Scand [Suppl] 285:11-20 